\title{
Morphometry and Vascularization of the Rabbit Kidneys (Oryctolagus cuniculus)
}

\author{
Morfometría y Vascularización del Riñón de Conejo (Oryctolagus cuniculus)
}

Santos-Sousa, C. A. ${ }^{* * *}$; Stocco, A. V."; Mencalha, R. ${ }^{* * *}$; Jorge, S. F. ${ }^{* * * *}$ \& Abidu-Figueiredo, M.

SANTOS-SOUSA, C. A.; STOCCO, A. V.; MENCALHA, R.; JORGE, S. F. \& ABIDU-FIGUEIREDO, M. Morphometry and vascularization of the rabbit kidneys (Oryctolagus cuniculus). Int. J. Morphol., 33(4):1293-1298, 2015.

SUMMARY: Rabbits have been used as urologic models in many studies. The aim of this study was to characterize the renal morphology and anatomical variations of the renal pedicle in rabbit. The research ethics committee of Rio de Janeiro Federal Rural University approved this study. The animals were obtained from the university's necropsy unit. Dissections were performed in 50 adult rabbits, male and females, without macroscopic renal pathology. Kidney measurements were made with a digital caliper: length, width, and thickness. The length and origin of the renal arteries and main branches and length of the renal veins were also determined. The terminology of Nomina Anatomica Veterinaria was followed. The mean and standard deviation of the length of the right kidney was $3.150 \pm 0.2588 \mathrm{~cm}$ in males and $3.127 \pm 0.3769 \mathrm{~cm}$ in females and in the left kidney was $3.083 \pm 0.0818 \mathrm{~cm}$ in males and $3.162 \pm 0.0848 \mathrm{~cm}$ in females. The width of the right kidney was $1.933 \pm 0.0848 \mathrm{~cm}$ in males and $1.996 \pm 0.0680 \mathrm{~cm}$ in females and in the left kidney was $1.850 \pm 0.0659 \mathrm{~cm}$ in males and $2.004 \pm 0.0940 \mathrm{~cm}$ in females. There was no significant difference in the measurements between the two sexes and antimeres and in the measures of renal vessels in relation to sex, but the left artery and renal vein were always larger than the right in both sexes. The results of the present study are expected to contribute to the body of knowledge in the field of comparative and applied anatomy.

KEY WORDS: Blood vessels; Kidney; Measurements; Variability; Rabbit.

\section{INTRODUCTION}

Morphometric features of kidneys and the relative organ weights are important parameters that can be used in pharmacological and toxicological studies in addition to the chemical and food industries (Michael et al., 2007). The morphological variation of various structures of living organisms is a common observable fact.

The renal dimensions in humans and animals are very useful diagnostic parameters both in urological as well as nephrologic practice.

The relevant applications of less invasive procedures, such as laparoscopy, endourology, extracorporeal shockwave lithotripsy (SWL), and conservative renal surgery, as well as other techniques to manage renal pathologic conditions, require experiments in appropriate animal models.

Study of laboratory animals provides information on various aspects, such as experimental surgical interventions, pathological mechanisms, effects of some drugs on the nervous system and other systems. This information can be applied not only to domestic animals but also to humans (Cizkova et al., 2001). Furthermore, as an excellent model species, rabbits help to investigate such conditions like arterial injury (Jorgensen et al., 1972), aortic occlusion (Mackey et al., 1997) and aortic aneurysm (Freestone et al., 1997). However, there is limited information about basic anatomy of the rabbit kidney.

Many animals have been used as experimental models for urologic procedures. Pigs are more often used because their kidney most closely resembles the structural features of the human kidney (Sampaio et al., 1998). On the other hand, rabbits have been used as urologic models in many studies, such as radiofrequency ablation (RFA) (Miao et al., 2001) magnetic resonance imaging (Hynynen et al., 1996), histotripsy (Roberts et al., 2006), lithotripsy (Fernández et al., 2009) and partial nephrectomy (Tyritzis et al., 2007).

* Department of Animal Biology, Animal Anatomy Area, Federal Rural University of Rio de Janeiro, Rio de Janeiro, Brazil.

** Postgraduate Program in Animal Biology, Federal Rural University of Rio de Janeiro, Rio de Janeiro, Brazil.

*** Department of Surgery and Anesthesiology, Faculty of Veterinary Medicine, Valença Higher Education Center, Valença, Brazil. Postgraduate Program in Veterinary Medicine, Federal Rural University of Rio de Janeiro, Rio de Janeiro, Brazil.

**** Department of Clinic and Surgery, Faculty of Veterinary Medicine, UNIFESO, Teresópolis, Brazil. Postgraduate Program in Veterinary Medicine, Federal Rural University of Rio de Janeiro, Rio de Janeiro, Brazil. 
Background knowledge of normal renal dimensions (RD) may help in the diagnosis of kidney diseases. Renal dimensional variations occur in nephropathies due to hypertrophic process and/or atrophy (Elkin, 1942). Thus, it is imperative to establish the pattern of normal renal dimensions. It has been postulated from necropsy studies that variations in RD and renal weight are related to gender with weight being higher in males. It is also known that the left kidney is larger than the right one, independent of gender (Moell, 1956). Data from necropsies are not universally accepted, since a wide variation in dimensions is observed, variability that has been confirmed by studies utilizing intravenous pyelography (IVP) (Moell).

Therefore, the purpose of this study was to gain a better understanding of the renal morphometry and anatomical variations of the renal pedicle in rabbit.

\section{MATERIAL AND METHOD}

The research ethics committee of Rio de Janeiro Federal Rural University approved this study (number 23083.002379/2007-08). Fixation was done by caudally injecting a $10 \%$ formaldehyde solution through the catheter (variable volume depending on the cadaver's weight). Immediately after fixation of the cadavers, Petrolátex S65 solution (Duque de Caxias Refinery, Petrobrás, Duque de Caxias, RJ - Brazil) mixed with Suvinil pigment was injected to fill the entire arterial system. Then each cadaver was immersed in a low-density polyethylene cardboard box with capacity of 500 liters containing a $10 \%$ formaldehyde solution to finalize the fixation and latex polymerization process.

Anatomical dissections were performed in 50 adult rabbits without macroscopic renal pathology: 25 males and 25 females. They weighed between 2.0 and $2.3 \mathrm{Kg}$ and their rostrum-sacral length was around $40 \mathrm{~cm}$. The animals were obtained from the university's necropsy unit. The abdomen was opened by an incision on the white line followed by another behind the last rib to expose the abdominal organs. The abdominal aorta artery was dissected immediately below the diaphragm until the emergence of the renal arteries. The abdominal aorta artery was cannulated with a plastic stem. The kidneys were "in situ" dissected to characterize the skeletopy. Kidney measurements were made with a digital caliper: length (distance between the cranial and caudal poles), width (distance between the medial and lateral borders), and thickness (distance between the dorsal and ventral surfaces). The length and origin of the renal arteries and main branches and length of the renal veins were also determined. The dissected materials were imaged using a Nikon Coolpix L820 model camera. The terminology of Nomina Anatomica Veterinaria was followed.

Statistical analysis. The mean and standard deviation of the kidney and renal vessel measurements were calculated and compared in both sexes by the unpaired t-test. To verify if the frequency distributions observed for the 50 animals were in accordance with the literature, the Chi-square $\left(x^{2}\right)$ test was performed to test the null hypothesis for skeletopy of the right and left kidneys. A value of $p<0.05$ was considered statistically significant.

\section{RESULTS}

Origin: In all animals dissected, the renal arteries emerged as a single vessel laterally directly from the abdominal aorta (Fig. 1).

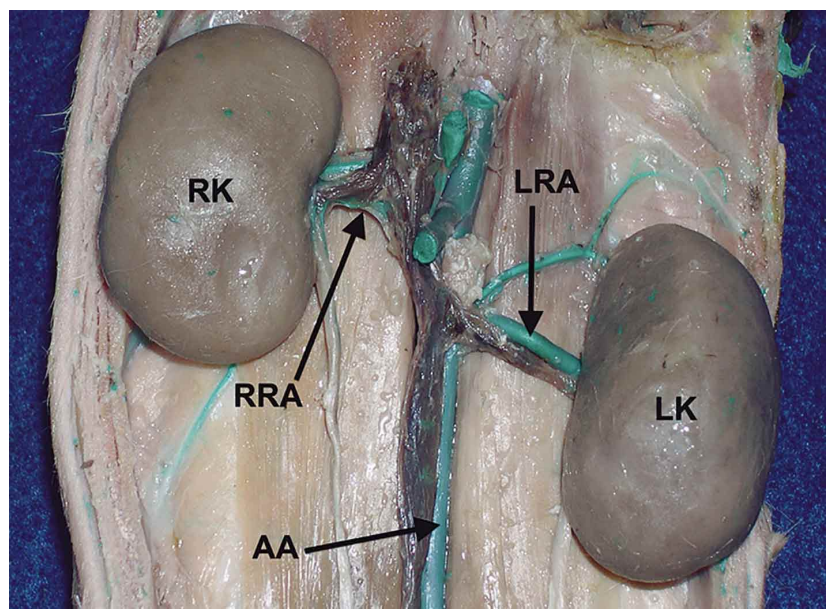

Fig. 1. Photomacrography of the origin of the renal arteries. $\mathrm{RK}=$ right kidney; $\mathrm{LK}=$ left kidney; $\mathrm{RRA}=$ right renal artery; $\mathrm{LRA}=$ left renal artery; $\mathrm{AA}=$ abdominal aorta.

Renal and vessel measurements: The results of the kidney and vessel measurements are shown in Tables I, II and III.

Renal artery skeletopy and variations: In males, the right renal artery originated at the level of the 1st lumbar vertebra in 2 animals ( $8 \%$ ), between $1^{\text {st }}$ and $2^{\text {nd }}$ in 8 animals (32\%) and in $2^{\text {nd }}$ lumbar vertebra in 15 animals (60\%). At its end, near the hilum, the right renal artery was present only in 6 animals (24\%), while there was bifurcation in 13 animals $(52 \%)$ and trifurcation in 6 animals $(24 \%)$. The right renal artery also issued the following branches: phrenic-abdominal, to the adrenal gland and to the ureter in 25 animals (100\%). 
Table I. Comparison of the kidney and vessel measurements in rabbits (Oryctolagus cuniculus) - both sexes (cm).

\begin{tabular}{lccc}
\hline & \multicolumn{2}{c}{ Rabbit } & \multirow{2}{*}{ P value } \\
\cline { 2 - 3 } & $3.150 \pm 0.258$ & $3.127 \pm 0.376$ & 0.803 \\
Length of the right kidney & $3.083 \pm 0.081$ & $3.162 \pm 0.084$ & 0.511 \\
Length of the left kidney & $1.933 \pm 0.084$ & $1.996 \pm 0.068$ & 0.563 \\
Width of the right kidney & $1.850 \pm 0.065$ & $2.004 \pm 0.094$ & 0.193 \\
Width of the left kidney & $1.533 \pm 0.038$ & $1.635 \pm 0.044$ & 0.093 \\
Thickness of the right kidney & $1.613 \pm 0.048$ & $1.669 \pm 0.055$ & 0.448 \\
Thickness of the left kidney & $2.013 \pm 0.078$ & $2.013 \pm 0.078$ & 0.705 \\
Length of the right renal artery & $2.379 \pm 0.087$ & $2.431 \pm 0.078$ & 0.661 \\
Length of the left renal artery & $1.708 \pm 0.089$ & $1.681 \pm 0.083$ & 0.834 \\
Length of the right renal vein & $2.446 \pm 0.0838$ & $2.269 \pm 0.0987$ & 0.182 \\
Length of the left renal vein & & &
\end{tabular}

Data expressed as Mean and SD.

Table II. Comparison of the kidney and vessel measurements between male rabbits (Oryctolagus cuniculus) (cm).

\begin{tabular}{lccc}
\hline & \multicolumn{2}{c}{ Males } & \multirow{2}{*}{ P value } \\
\cline { 2 - 3 } & \multicolumn{1}{c}{ Right } & Left & \\
\hline Renal length & $3.150 \pm 0.2588$ & $3.083 \pm 0.0818$ & 0.4980 \\
Renal width & $1.933 \pm 0.0848$ & $1.850 \pm 0.0659$ & 0.4420 \\
Renal thickness & $1.533 \pm 0.0388$ & $1.613 \pm 0.0482$ & 0.2078 \\
Renal artery length & $2.013 \pm 0.0783$ & $2.379 \pm 0.0870$ & $0.0030^{* *}$ \\
Renal vein length & $1.708 \pm 0.0890$ & $2.446 \pm 0.0838$ & $<0.0001^{* * *}$ \\
\hline
\end{tabular}

Data expressed as Mean and SD. $* * \mathrm{p}<0.01 ; * * * \mathrm{p}<0.001$.

Table III. Comparison of the kidney and vessel measurements between female rabbits $(\mathrm{cm})$.

\begin{tabular}{lccc}
\hline & \multicolumn{2}{c}{ Female } & \multirow{2}{*}{ P value } \\
\cline { 2 - 3 } & Right & Left & \\
\hline Renal length & $3.127 \pm 0.0739$ & $3.162 \pm 0.0848$ & 0.7597 \\
Renal width & $1.996 \pm 0.0680$ & $2.004 \pm 0.0940$ & 0.9474 \\
Renal thickness & $1.635 \pm 0.0440$ & $1.669 \pm 0.0556$ & 0.6279 \\
Renal artery length & $2.058 \pm 0.0884$ & $2.431 \pm 0.0786$ & $0.0027^{*}$ \\
Renal vein length & $1.681 \pm 0.0952$ & $2.269 \pm 0.0987$ & $<0.0001^{* *}$ \\
\hline Data expressed as Mean and SD. $* * \mathrm{p}<0.01 ; * * *<<0.001$. &
\end{tabular}

The left renal artery originated at the level of the 1st lumbar vertebra in 2 animals (8\%), between $1^{\text {st }}$ and $2^{\text {nd }}$ in 1 animal (4\%), $2^{\text {nd }}$ lumbar vertebra in 8 animals $(32 \%)$, and between $2^{\text {nd }}$ and $3^{\text {rd }}$ lumbar vertebrae in 14 animals (56\%). At its end, near the hilum, the left renal artery was present only in 4 animals (16\%), while there was bifurcation in 16 animals (64\%) and trifurcation in 5 animals (20\%). The left renal artery also issued the following branches: phrenicoabdominal, to the adrenal gland and to the ureter in 24 animals (96\%).

In females, the right renal artery originated at the level of the 1st lumbar vertebra in 5 animals $(20 \%)$, between the $1^{\text {st }}$ and $2^{\text {nd }}$ lumbar vertebrae in 8 animals ( $32 \%$ ), and in the $2^{\text {nd }}$ lumbar vertebra in 12 animals $(48 \%)$. At its end, near the hilum, the right renal artery was present only in 4 animals (16\%), while there was bifurcation in 18 animals $(72 \%)$ and trifurcation in 3 animals (12\%). The right renal artery also issued the following branches: phrenicoabdominal, to the adrenal gland and to the ureter in 25 animals (100\%).

The left renal artery originated at the level of the $1^{\text {st }}$ lumbar vertebra in 2 animals (8\%), between $1^{\text {st }}$ and $2^{\text {nd }}$ in 5 animals $(20 \%)$, in the $2^{\text {nd }}$ lumbar vertebra in 7 animals $(28 \%)$, between $2^{\text {nd }}$ and $3^{\text {rd }}$ lumbar vertebrae in 9 animals $(36 \%)$ and in the $3^{\text {rd }}$ lumbar vertebra in 2 animals $(8 \%)$. At its end, near the hilum, the left renal artery was present only in 4 animals (16\%), while there was bifurcation in 19 animals $(76 \%)$ and trifurcation in 2 animals (8\%). The left renal artery also issued the following branches: phrenicoabdominal, to the adrenal gland and to the ureter in 25 animals (100\%).

Renal skeletopy: In males, the right kidney was observed positioned between T13 L2 in 7 animals (28\%), T12 - L3 in 2 (8\%), L1 $\mathrm{L} 4$ in $3(12 \%), \mathrm{L} 1-\mathrm{L} 2$ in 2 (8\%), L2 - L4 in 2 (8\%), L3 - L5 in 2 (8\%), T13 - L3 in 4 (16\%) and between L1 - L3 in $3(12 \%)$. The left kidney was observed between L2 - L4 in 10 (40\%), L3 - L5 in 6 (24\%), L2 - L3 in 2 (8\%), L4 - L6 in 3 (12\%), L4 - L5 in 2 (8\%) and between L3 - L4 in 2 animals $(8 \%)$.

In females, the right kidney was observed positioned betweenT13 - L2 in 1 animal (4\%), L1 - L4 in 3 animals (12\%), L2 - L3 in 1 (4\%), L2 - L4 in 1 animal (4\%), T12 - L3 in 1animal (4\%), T13 - L4 in 3 animals (12\%), T13 - L3 in 3 animals (12\%), and between L1 - L3 in 12 animals (48\%). The left kidney was observed between L2 - L4 in 3 animals (12\%), L3 - L5 in 12 animals (48\%), L2 - L5 in 2 animals (8\%) and between L4 - L6 in 8 animals (32\%). 


\section{DISCUSSION}

Renal Measurements. Morphometry is the scientific study of the dimensions of gross anatomical structures of organisms, with particular reference to their linear measurements and weights. These are often obtained by direct measurements of formalin-fixed specimens, especially of the brain. Results have varied and accuracies are still being discussed (Peters et al., 2000).

Renal length and volume measurements are clinically relevant, serving as surrogates for renal functional reserve, and are used frequently as the basis for making clinical decisions. Serial measurements can also provide information regarding disease progression or stability. Renal disease can increase or decrease kidney size, and may or may not be accompanied by changes to the normal organ structure.

Nine hundred and four normal intravenous pyelographs, 581 from men and 323 from women, were analyzed in a previous study (Fernandes et al., 2002). Data obtained by measurement of right and left kidneys agreed with data from other studies, showing that the left kidney is larger than the right (Sampaio \& Mandarin-de-Lacerda, 1989).

A recent study associated the renal length to several anthropometric variables in a group of healthy Mexican adults and concluded that renal size and height were shorter in that population compared with figures published Europeans (Oyuela-Carrasco et al., 2009). They also noted that the left renal length was significantly greater than right renal length and also that both renal lengths were greater in men than women in that population.

An ultrasonography study of human renal dimensions in normal adult population of northeastern India, in both sexes and different ages (Gupta et al., 2013), found no significant differences in any of the renal dimensions between the right and left kidneys in either sex, although the dimensions of the left kidney were somewhat greater than the right. An important observation made was that there was a significant difference $(\mathrm{p}<0.01)$ in the width of both the kidneys when comparing them between the male and female population. Similarly, there was a significant difference $(p=0.008)$ in the size of the left kidney between the two sexes.

In the present study there was no significant difference seen in any of the renal dimensions between the right and left kidneys in either sex.

In a study with nine male rabbits comparing fresh and fixed kidneys in formalin solution, Bolat et al. (2011) observed an increase of weight after fixation in both kidneys. They also found a decrease in the right kidney thickness after fixation. It was observed that the left kidneys were more affected by formalin fixation than right kidneys. No differences were observed in renal measures, similar to that observed in our study, which were compared antimeres and sex.

Renal vessels. In rabbits, every renal artery emits a caudal adrenal branch, sometimes up to two or three, along with a ureteric branch (Barone, 1996). However, another study (Bavaresco et al., 2013) found the phrenic-abdominal artery and occasionally one of the adrenal arteries as a side branch of the renal artery, which does not coincide with the literature referred to above. In the present investigation, the right and left renal arteries issued the phrenic-abdominal artery, adrenal branches and ureteric branches.

The renal arteries in rabbits, golden hamsters and nutrias originate from the abdominal aorta laterally and caudally to the issuance of the cranial mesenteric artery and, in general, show asymmetrical layout, with the right vessel more cranial than the left vessel (Barone et al.). In nutrias, a double renal artery was observed in the kidneys of 3.3\% of animals, both right and left (Culau et al., 2008). In the year prior to this study, some researchers observed that in all animals asymmetry was observed at the place of origin of the renal arteries, and the right cranial vessel was always more cranial than the left. However, the presence was not detected of double renal artery, but, in the absence one case, to the left, because the left kidney agenesis (Bavaresco et al.). These results are similar to those obtained in the present investigation, but no renal agenesis was observed here. However, other authors have described the presence of double left renal artery.

According to Ahasan et al. (2012) in rabbit, the renal arteries descend from the abdominal aorta. Although the origin of both renal arteries from the abdominal aorta varied, right renal artery descended cranial to the left renal arteries in $27(96.43 \%)$ cases. Similar relation was observed in 14 species (Human, Chimpanzee, Baboon, Pig tailed monkey, Stump faced monkey, Capuchin, greater Japanese shrew mole, lesser Japanese mole, rat, mongoose, mouse, rabbit, dog, hippopotamus). But in a single case both renal artery originated at same level. The same relation was reported in gibbon, marmoset, loris and pig (Yokota et al., 2005).

In the same experiment, a difference was observed between the right and left renal artery lengths, similar to that observed in the present study, where the left renal artery was higher than the right in both sexes. 
The rabbit is increasingly becoming a model of choice for training purposes in microvascular surgery and more importantly for research in the biological sciences. Ease of handling, relatively low cost and a good understanding of this species pathophysiology are some of the factors responsible for the widespread acceptance of this animal model. Therefore, research in rabbit anatomy should be encouraged for better comprehension of this animal.

There was no significant difference in the renal measurements between the sexes and antimeres. The left artery and renal vein were always larger than the right in both sexes.
The present study obtained results that are expected to contribute to the body knowledge in the field of comparative and applied anatomy, thus, providing subsidies for experimental, radiological and surgical practice in urology and nephrology.

\section{ACKNOWLEDGEMENTS}

National Council of Technological and Scientific Development (CNPq), Rio de Janeiro Research Foundation (FAPERJ).

SANTOS-SOUSA, C. A.; STOCCO, A. V.; MENCALHA, R.; JORGE, S. F. \& ABIDU-FIGUEIREDO, M. Morfometría y vascularización del riñón de conejo (Oryctolagus cuniculus). Int. J. Morphol., 33(4):1293-1298, 2015.

RESUMEN: Los conejos se han utilizado como modelos urológicos en muchas investigaciones. El objetivo de este estudio fue caracterizar la morfología renal y variaciones anatómicas del pedículo renal en el conejo. El comité de ética de la investigación de Río de Janeiro Universidad Federal Rural aprobó este estudio. Los animales se obtuvieron de unidad de necropsia de la universidad. Las disecciones se realizaron en 50 conejos adultos, machos y hembras, sin patología renal macroscópica. Se realizaron con un calibrador digital las siguientes mediciones en el riñón : longitud, ancho y grosor. También se determinaron la longitud y el origen de las arterias renales y ramas principales y longitud de las venas renales. Se siguió la terminología de Nomina Anatomica Veterinaria. La Media y DE de la longitud del riñón derecho fue $3,150 \pm 0,2588 \mathrm{~cm}$ en machos y 3,127 $\pm 0,3769 \mathrm{~cm}$ en hembras y en el riñón izquierdo fue $3,083 \pm 0,0818$ $\mathrm{cm}$ en machos y 3,162 $\pm 0,0848 \mathrm{~cm}$ en hembras. El ancho del riñón derecho fue 1,933 $\pm 0,0848 \mathrm{~cm}$ en machos y 1,996 $\pm 0,0680 \mathrm{~cm}$ en las hembras y en el riñón izquierdo fue $1,850 \pm 0,0659 \mathrm{~cm}$ en machos y 2,004 $\pm 0,0940 \mathrm{~cm}$ en hembras. No hubo diferencias significativas en las mediciones entre los dos sexos y los antímeros, así como en las medidas de los vasos renales en relación con el sexo; pero la arteria y vena renal izquierda fueron siempre mayores que las del lado derecho en ambos sexos. Se espera con los resultados del presente estudio contribuir al conocimientos en el campo de la anatomía comparada y aplicada.

PALABRAS CLAVE: Vasos sanguíneos; Riñones; Mediciones; Variabilidad; Conejo.

\section{REFERENCES}

Ahasan, A. S. M. L.; Islam, M. S.; Kabria, A. S. M. G.; Rahman, M. L.; Hassan, M. M. \& Uddin, M. major variation in branches of the abdominal aorta in New Zealand white rabbit (Oryctolagus cuniculus). Int. J. Nat. Sci., 2(4):91-8, 2012.

Almeida, B. B.; Araújo-Barreto, U. H.; Costa, O. M. \& AbiduFigueiredo, M. Double renal artery in rabbits. Biosci. J., 29(5):1295-9, 2013.

Barone, R. Comparative anatomy of domestic mammals: Angiology. 2nd ed. Paris, Vigot, 1996.

Bavaresco, A. Z.; Culau, P. O. V. \& Campos, R. Visceral collateral branches of the abdominal aorta in New Zealand rabbits (Oryctolagus cuniculus). Acta Sci. Vet., 41:1131-1136, 2013.

Bolat, D.; Bahar, S.; Selçuk, M. L. \& Tipirdamaz, S. Morphometric investigations of fresh and fixed rabbit kidney. Eurasian $J$. Vet. Sci., 27(3):149-54, 2011.
Cizkova, D.; Kafka, J.; Cizek, M.; Sevcik, A. \& Marsala, J. The cauda equina syndrome induces synthesis of stress proteins. Psychiatry, 5(1):15-6, 2001.

Culau, P. O. V.; Azambuja, R. C. \& Campos, R. Ramos colaterais viscerais da artéria aorta abdominal em Myocastor coypus (nutria). Acta Sci. Vet., 36(3):241-7, 2008.

Elkin, M. Radiology of the Urinary System. Boston, Little Brown, 1942.

Fernandes, M. M.; Lemos, C. C.; Lopes, G. S.; Madeira, E. P.; Santos, O. R.; Dorigo, D. \& Bregman, R. Normal renal dimensions in a specific population. Int. Braz. J. Urol., 28(6):510-5, 2002.

Fernández, F.; Fernández, G. \& Loske, A. M. Treatment time reduction using tandem shockwaves for lithotripsy: an in vivo study. J. Endourol., 23(8):1247-53, 2009. 
Freestone, T.; Turner, R. J.; Higman, D. J.; Lever, M. J. \& Powel, J. T. Influence of hypercholesterolemia and adventitial inflammation on the development of aortic aneurysm in rabbits. Arterioscler. Thromb. Vasc. Biol., 17(1):10-7, 1997.

Gupta, S.; Devi, N. D.; Sinam, S. S.; Khumukcham, S. \& Singh, A. K. Ultrasonographic renal dimensions in normal adult population of North-East India. Int. J. Med. Health Sci., 2(4):433-7, 2013.

Hynynen, K.; Colucci, V.; Chung, A. \& Jolesz, F. Noninvasive arterial occlusion using MRI-guided focused ultrasound. Ultrasound Med. Biol., 22(8):1071-7, 1996.

Jorgensen, L.; Packham, M. A.; Rowsell, H. C. \& Mustard, J. F. Deposition of formed elements of blood on the intima and signs of intimal injury in the aorta of rabbit, pig, and man. Lab. Invest., 27(3):341-50, 1972.

Mackey, M. E.; Wu, Y.; Hu, R.; DeMaro, J. A.; Jacquin, M. F.; Kanellopoulos, G. K.; Hsu, C. Y. \& Kouchoukos, N. T. Cell death suggestive of apoptosis after spinal cord ischemia in rabbits. Stroke, 28(10):2012-7, 1997.

Miao, Y.; Ni, Y.; Bosmans, H.; Yu, J.; Vaninbroukx, J.; Dymarkowski, S.; Zhang, H. \& Marchal, G. Radiofrequency ablation for eradication of renal tumor in a rabbit model by using a cooled-tip electrode technique. Ann. Surg. Oncol., 8(8):651-7, 2001.

Michael, B.; Yano, B.; Sellers, R. S.; Perry, R.; Morton, D.; Roome, N.; Johnson, J. K.; Schafer, K. \& Pitsch, S. Evaluation of organ weights for rodent and non-rodent toxicity studies: a review of regulatory guidelines and a survey of current practices. Toxicol. Pathol., 35(5):742-50, 2007.

Moell, H. Size of normal kidneys. Acta radiol., 46(5):640-5, 1956.

Oyuela-Carrasco, J.; Rodríguez-Castellanos, F.; Kimura, E.; Delgado-Hernández, R. \& Herrera-Félix, J. P. Renal length measured by ultrasound in adult mexican population. Nefrologia, 29(1):30-4, 2009.

Peters, M.; Jäncke, L. \& Zilles, K. Comparison of overall brain volume and midsagittal corpus callosum surface area as obtained from NMR scans and direct anatomical measures: a within-subject study on autopsy brains. Neuropsychologia, 38(10):1375-81, 2000.

Roberts, W. W.; Hall, T. L.; Ives, K.; Wolf, J. S. Jr.; Fowlkes, J. B. \& Cain, C. A. Pulsed cavitational ultrasound: a noninvasive technology for controlled tissue ablation (histotripsy) in the rabbit kidney. J. Urol., 175(2):734-8, 2006.

Sampaio, F. J. \& Mandarim-de-Lacerda, C. A. Morphometry of the kidney. Applied study in urology and imaging. J. Urol. (Paris), 95(2):77-80, 1989.
Sampaio, F. J.; Pereira-Sampaio, M. A. \& Favorito, L. A. The pig kidney as an endourologic model: anatomic contribution. $J$. Endourol., 12(1):45-50, 1998.

Tyritzis, S. I.; Kyroudi, A.; Liatsikos, E.; Manousakas, T.; Karayannacos, P.; Kostomitsopoulos, N.; Zervas, A.; Pavlakis, K.; Stolzenburg, J. U. \& Constantinides, C. Comparison of prolonged warm and cold ischemia on the solitary kidney during partial nephrectomy in a rabbit model. World J. Urol., 25(6):635-40, 2007.

Yokota, E.; Kawashima, T.; Ohkubo, F. \& Sasaki, H. Comparative anatomical study of the kidney position in amniotes using the origin of the renal artery as a landmark. Okajimas Folia. Anat. Jap., 81(6):135-42, 2005.

Correspondence to:

Marcelo Abidu-Figueiredo

Department of Animal Biology

Animal Anatomy Area

Federal Rural University of Rio de Janeiro - UFRRJ

Rio de Janeiro

BRAZIL

Email: marceloabidu@gmail.com

Received: 12-06-2015

Accepted: 25-09-2015 